慶應義塾大学学術情報リポジトリ

Keio Associated Repository of Academic resouces

\begin{tabular}{|c|c|}
\hline Title & $\begin{array}{l}\text { Structure and hypotensive activity relationships of tetrandrine derivatives in stroke-prone } \\
\text { spontaneously hypertensive rats }\end{array}$ \\
\hline \multicolumn{2}{|l|}{ Sub Title } \\
\hline Author & $\begin{array}{l}\text { 川島, 紘一郎(Kawashima, Koichiro) } \\
\text { 早川, 晃正(Hayakawa, Terumasa) } \\
\text { 三輪, 裕子(Miwa, Yuko) } \\
\text { 大畑, 尚代(Ohata, Hisayo) } \\
\text { 鈴木, 岳之(Suzuki, Takeshi) } \\
\text { 藤本, 和子(Fujimoto, Kazuko) } \\
\text { 荻野, 達則(Ogino, Tatsunori) } \\
\text { 陳, 政雄(Chen, Zhengxiong) }\end{array}$ \\
\hline Publisher & 共立薬科大学 \\
\hline Publication year & 1990 \\
\hline Jtitle & $\begin{array}{l}\text { 共立薬科大学研究年報 (The annual report of the Kyoritsu College of } \\
\text { Pharmacy). No.35 (1990. ) , p.64- } 64\end{array}$ \\
\hline \multicolumn{2}{|l|}{ JaLC DOI } \\
\hline \multicolumn{2}{|l|}{ Abstract } \\
\hline Notes & 抄録 \\
\hline Genre & Technical Report \\
\hline URL & $\begin{array}{l}\text { https://koara.lib.keio.ac.jp/xoonips/modules/xoonips/detail.php?koara_id=AN00062898-0000003 } \\
\text { 5-0064 }\end{array}$ \\
\hline
\end{tabular}

慶應義塾大学学術情報リポジトリ(KOARA)に掲載されているコンテンツの著作権は、それぞれの著作者、学会または出版社/発行者に帰属し、その権利は著作権法によって 保護されています。引用にあたっては、著作権法を遵守してご利用ください。

The copyrights of content available on the KeiO Associated Repository of Academic resources (KOARA) belong to the respective authors, academic societies, or publishers/issuers, and these rights are protected by the Japanese Copyright Act. When quoting the content, please follow the Japanese copyright act. 


\section{Structure and Hypotensive Activity Relationships of Tetrandrine Derivatives in Stroke-Prone Spontaneously Hypertensive Rats*}

Koichiro Kawashima, Terumasa Hayakawa, Yuko Miwa, Hisayo Oohata, Takeshi Suzuki, Kazuko Fujimoto, Tatsunori Ogino** and Zhengxiong Chen (Masao ChIN)** 川島紘一郎, 早川晃正, 三輪裕子, 大畑尚代, 鈴木岳之, 藤本和子, 荻野達則**, 陳 政雄**

1. Structure and hypotensive activity relationships of tetrandrine (TD), an alkaloid isolated from the Chinese herb Redix stephaniae tetrandrae and its derivatives were investigated in conscious stroke-prone spontaneously hypertensive rats (SHRSP).

2. Derivatives substituted at the $7-O$ position with various types of alkyl group produced varying degrees of hypotensive effect.

3 While the demethylated derivative, fangchinoline (FC), and its acetylated compound had no effect on blood pressure, 7-O-methyl FC (TD), and 7-O-ethyl and $7-O$-isopropyl $\mathrm{FC}$ at oral doses of 25 and $50 \mathrm{mg} / \mathrm{kg}$ produced a gradual and sustained hypotensive effect without any significant effects on heart rate and plasma renin concentration.

4. Substitution at the 7-O position with longer side chains such as n-propyl, n-butyl and n-pentyl groups reduced both the degree and duration of hypotensive activity.

5. Substitution of $N$-methyl groups at the 2 and 2' positions with quaternary ammonium or $N$-oxide attenuated the hypotensive activity.

6. The results of this study suggest a possibility that 7-O-ethyl and 7-Oisopropyl derivatives as well as TD can be considered as potential antihypertensive drugs because of the gradual onset and long duration of their hypotensive action in SHRSP.

* 本報告は Gen. Pharmac. Vol. 21, No. 3, pp. 343-347, 1990 に発表.

** 津村研究所 